\title{
ASSESMENT OF LEAD IN WATER, SEDIMENTS, SOILS AND VEGETABLES GROWN ON THE BANK OF SHITALAKHYA RIVER, BANGLADESH
}

\author{
A. N. M. AL-RAZEE, MD. NURUL ABSER ${ }^{*}$, MD. ABDUL MOTTALIB $^{1}$ AND \\ MD. ZAHED HOSSIEN ANSARY ${ }^{2}$ \\ Department of Chemistry, Jahangirnagar University, Savar, Dhaka, Bangladesh
}

\begin{abstract}
The study was carried out to examine the $\mathrm{Pb}$ concentrations of water, sediment and soil of Shitalakhya River at Polash and Ghorashal areas in Bangladesh. The ranges of $\mathrm{Pb}$ in water, sediments, soils and vegetables like pumpkin leaves and alligator weeds were found $1.87-49.08$, 8.49 - 75.81, 19.68 - 85.13, 1.08 - 3.92 and 1.18 - $4.22 \mathrm{mg} / \mathrm{kg}$, respectively. The lead concentrations of surface water, sediment and soil samples were within the safe limit of different international standard except samples of the point source of urea fertilizer factory. The highest concentrations of $\mathrm{Pb}$ in alligator weeds and pumpkin vegetable leaves were recorded 3.92 and $4.224 \mathrm{mg} / \mathrm{kg}$, respectively at the point source of urea fertilizer factory.
\end{abstract}

Key words: Point source, $\mathrm{Pb}$, Alloy, White metal, Shitalakhya

\section{INTRODUCTION}

$\mathrm{Pb}$ is very toxic to humans. This is only tolerable at extremely at low concentration and excesses are associated with many adverse health effects. Exposure to $\mathrm{Pb}$ has been associated with reduced IQ, learning disabilities, slow growth, hyperactivity, and antisocial behaviors and impaired hearing (Dahiya et al. 2005). Generally Pb-poisoning is ranked as the most common environmental health hazard. The US EPA has classified $\mathrm{Pb}$ as a probable human carcinogen (Adriano 2001).

The Shitalakhya River generated from old Brahmaputra at Tok of greater Mymensingh. This flows south, touching the eastern part of Dhaka city and flowing through Narayanganj and meets Meghna River at Kolagachia of Monshiganj. In recent years, the Polash area of Narsingdi has become one of the rapidest developing regions in Bangladesh. The Shitalakhya River receives effluents from five jute mills, two fertilizer factories, one sugar mill, one cement industry, one textile industry, one dairy plant, two food processing industries, one hardboard mill, one paper mill and one of joint thermal power plant within $13 \mathrm{~km}$ range of its flow in Ghorashal region. Shitalakhya River is the

\footnotetext{
*Corresponding author: < abserju@yahoo.com>.

${ }^{1}$ Institute of Leather Engineering and Technology, University of Dhaka, Dhaka-1209, Bangladesh.

${ }^{2}$ Department of Analytical Chemistry \& Environmental Science, Training Institute for Chemical Industries, Polash, Narsingdi-1611, Bangladesh.
} 
main source of industrial and drinking water in this region. Surface water is used in industry for cooling, process, steam generation, safety and miscellaneous purposes. The present study was focused on the investigation of the contamination level of $\mathrm{Pb}$ in water, sediments, soils and vegetables grown on the bank of Shitalakhya River near PolashGhorashal region where many red and orange category industries are situated. The aim of this study is to explore the natural and industrial impacts of $\mathrm{Pb}$ and to assess the pollution status on that area.

\section{MATERIALS AND METHODS}

Surface waters were collected from Polash fertilizer factories area and Capital paper mill in Ghorashal region. Three sampling locations such as fertilizer factories, Seven Ring Cement industry and Capital paper mill areas were selected for soil and sediment.

Nine samples of surface water from the different sampling stations were collected in monsoon and pre-monsoon seasons distinctly. Surface water samples were collected away from the river bank and close to mid width of the river and a depth of about $20-25$ $\mathrm{cm}$ below the water surface. The water samples were collected in plastic bottles and acidified immediately with $2 \mathrm{ml}$ of $\mathrm{HNO}_{3}$ per liter of water and preserved in refrigerator at $4^{\circ} \mathrm{C}$ for laboratory analysis.

Sediment sampling was carried out from December, 2011 to July, 2012 for three seasons namely, dry season (December), pre-monsoon (March) and monsoon (July). On the other hand, soil sampling was carried out in pre-monsoon, 2012 (March). About 200 $\mathrm{g}$ of each wet soil and sediment were collected and transferred into the pre-cleaned plastic bags. The air dried soil/sediment samples were finely powered and sieved through a 2mm nylon mesh to remove large debris, stones and pebbles. Then the samples were dried at $105^{\circ} \mathrm{C}$ for 2 hours to remove all the moisture content and ground to pass through 60 mesh sieves and homogenized for analysis. Then the dried samples were digested.

Vegetable samples were collected randomly on March, 2011 from the bank of the river. Nine alligator weeds and four pumpkin vegetable leaves were collected by hand using vinyl gloves, carefully packed into polyethylene bags. The plant samples were precleaned by tap water and finally cleaned with deionized water to remove airborne pollutants. Then the samples were cut into $2-\mathrm{cm}$ pieces and dried in a hot air oven at 70 $80^{\circ} \mathrm{C}$ till the constant weight was achieved. The dried samples were ground in a stainless steel blender and then passed through a $2 \mathrm{~mm}$ sieve.

The water samples were digested with $\mathrm{HNO}_{3}$ (APHA 1989). Sediment and soil samples were digested according to the $\mathrm{HNO}_{3} / \mathrm{HClO}_{4}$ digestion method (ASTM 2003). Vegetables were digested according to the $\mathrm{HNO}_{3} / \mathrm{HClO}_{4}$ method (Sullivan and Carpenter 1993). All reagents used were Merck analytical grade. 

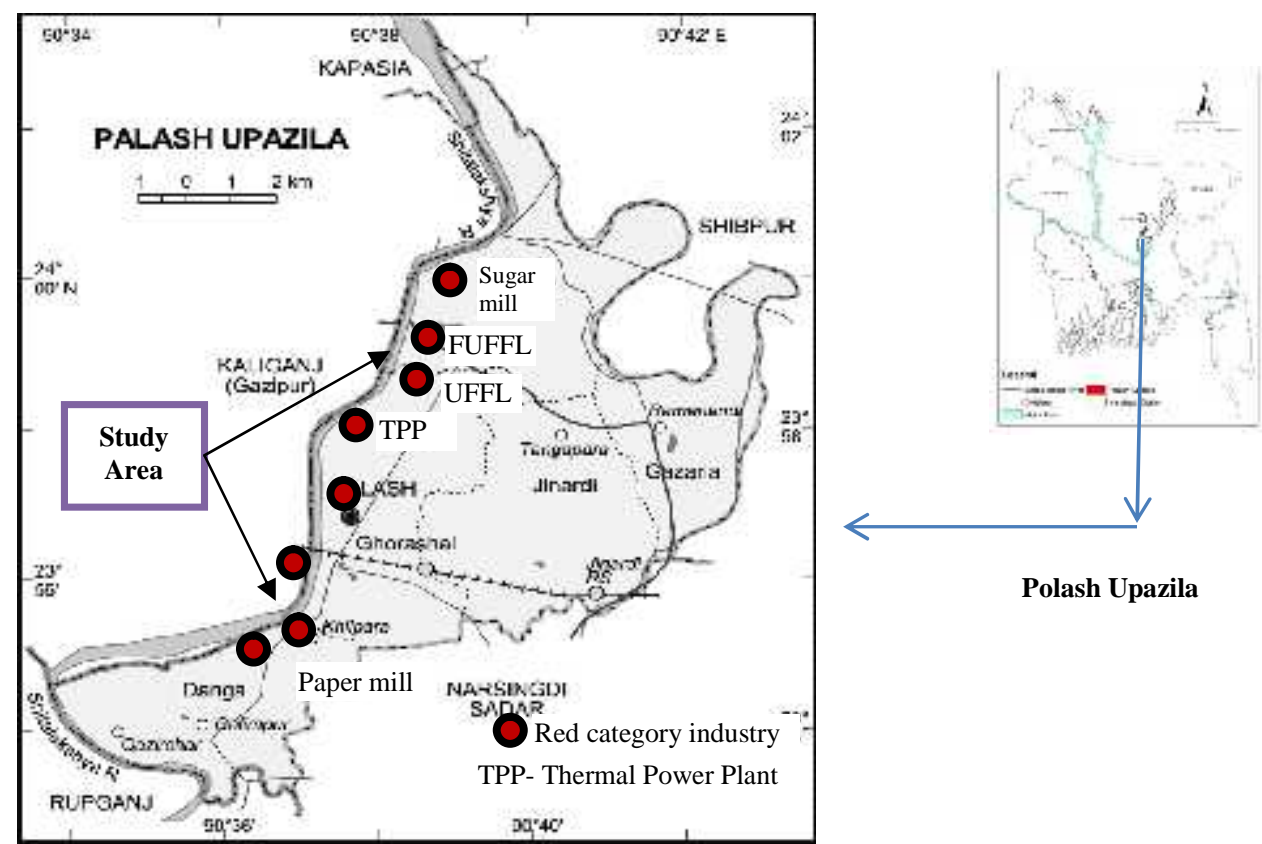

Fig. 1. Study area map.

Table 1. Locations of the sampling stations of sediment, soil, water and plants along the Shitalakhya River basin in Polash-Ghorashal region.

\begin{tabular}{|c|c|c|c|c|c|c|c|}
\hline Region & Sediment & Soil & Water & Plant & $\begin{array}{l}\text { Direction } \\
\text { UP/down }\end{array}$ & $\begin{array}{l}\text { Distance } \\
\text { from *P.S. } \\
\text { of UFF }\end{array}$ & Description \\
\hline \multirow{10}{*}{$\begin{array}{l}\text { Fertilizer } \\
\text { factories } \\
\text { region }\end{array}$} & $\mathrm{F}_{\mathrm{Sd} 1}$ & $\mathrm{~F}_{\mathrm{S} 1}$ & - & $\mathrm{F}_{1}$ & Upstream & 100 meter & \multirow{5}{*}{ Near P.S. of UFF } \\
\hline & - & - & $\mathrm{F}_{\mathrm{SW} 1}$ & - & $"$ & $20 "$ & \\
\hline & $\mathrm{F}_{\mathrm{Sd} 2}$ & $\mathrm{~F}_{\mathrm{S} 2}$ & $\mathrm{~F}_{\mathrm{SW} 2}$ & $\mathrm{~F}_{2}$ & Downstream & $03 ״$ & \\
\hline & - & - & $\mathrm{F}_{\mathrm{SW} 3}$ & - & $”$ & $20 "$ & \\
\hline & - & - & $\mathrm{F}_{\mathrm{SW} 4}$ & - & $"$ & $100 "$ & \\
\hline & \multirow[t]{2}{*}{$\mathrm{F}_{\mathrm{Sd} 3}$} & \multirow[t]{2}{*}{$\mathrm{F}_{\mathrm{S} 3}$} & - & $\mathrm{F}_{3}$ & $"$ & $400 \quad "$ & \multirow{3}{*}{ Near P.S. of PUFF } \\
\hline & & & $\mathrm{F}_{\mathrm{SW} 5}$ & & $"$ & $600 "$ & \\
\hline & $\mathrm{F}_{\mathrm{Sd} 4}$ & $\mathrm{~F}_{\mathrm{S} 4}$ & & $\mathrm{~F}_{4}$ & $"$ & 800 & \\
\hline & - & $\mathrm{F}_{\mathrm{S} 5}$ & - & - & $"$ & $150 "$ & $\begin{array}{l}\text { Opposite from P.S. of } \\
\text { UFF }\end{array}$ \\
\hline & - & $\mathrm{F}_{\mathrm{S} 6}$ & - & - & $"$ & 500 & $\begin{array}{l}\text { Opposite from P.S. of } \\
\text { UFF }\end{array}$ \\
\hline \multirow{2}{*}{$\begin{array}{l}\text { Cement } \\
\text { industry }\end{array}$} & $\mathrm{C}_{\mathrm{Sd} 1}$ & $\mathrm{C}_{\mathrm{S} 1}$ & $\mathrm{C}_{\mathrm{Sw1}}$ & - & $"$ & $10 \mathrm{Km}$ & \multirow[t]{2}{*}{ Seven ring cement area } \\
\hline & $\mathrm{C}_{\mathrm{Sd} 2}$ & $\mathrm{C}_{\mathrm{S} 2}$ & $\mathrm{C}_{\mathrm{Sw} 2}$ & - & $"$ & $11 "$ & \\
\hline \multirow{3}{*}{$\begin{array}{l}\text { Paper } \\
\text { mill }\end{array}$} & $\mathrm{P}_{\mathrm{Sd} 1}$ & $\mathrm{P}_{\mathrm{S} 1}$ & $\mathrm{P}_{\mathrm{Sw1}}$ & - & $"$ & $12 "$ & \multirow{3}{*}{$\begin{array}{l}\text { Capital paper mill area } \\
\text { P.S. of Capital Paper } \\
\text { mill }\end{array}$} \\
\hline & $\mathrm{P}_{\mathrm{Sd} 2}$ & $\mathrm{P}_{\mathrm{S} 2}$ & $\mathrm{P}_{\mathrm{Sw} 2}$ & - & $"$ & $13 "$ & \\
\hline & $\mathrm{P}_{\mathrm{Sd} 3}$ & $\mathrm{P}_{\mathrm{S} 3}$ & $\mathrm{P}_{\mathrm{Sw} 3}$ & - & $"$ & $14 "$ & \\
\hline
\end{tabular}


*P.S.: Point Source, UFF: Urea fertilizer factory; PUFF: Polash urea fertilizer factory

The concentration of $\mathrm{Pb}$ in the samples was determined by AAS (Model No.120, Graphite Tube Atomizer, AAS, Agilent, Australia). The calibration curve for $\mathrm{Pb}$ was prepared by certified reference materials (CRM). The CRM were verified against SRM 3100 series developed by NIST via ICP-OES using an internal laboratory developed method. The uncertainty in the certificate value of CRM was calculated for a $95 \%$ confidence interval.

\section{RESULTS AND DISCUSSION}

This study revealed that the concentration of $\mathrm{Pb}$ in surface water at the different points of Shitalakhya River at Polash region in pre-monsoon season ranged from 1.87 to $23.03 \mu \mathrm{g} / \mathrm{L}$ and in monsoon ranged from 27.86 to $49.08 \mu \mathrm{g} / \mathrm{L}$.

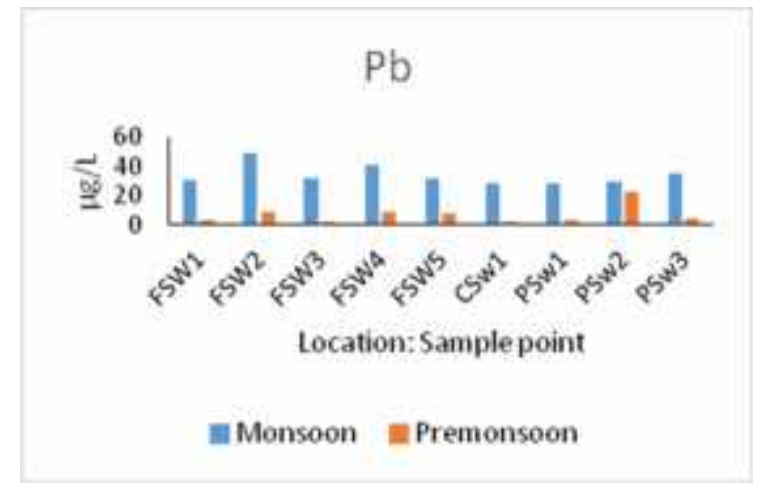

Fig. 2. Seasonal variation of $\mathrm{Pb}$ in surface water (duration: March to July, 12).

In all the points, lead concentration is higher in monsoon than pre-monsoon. This may be due to the flushing of the metal from immobilized deposits like domestic, natural and industrial sludge in rainy season. The results $(1.87-49.08 \mu \mathrm{g} / \mathrm{L})$ were below the recommended values for the protection of humans by US EPA (Sittig 1991). The highest concentration was recorded $(49.08 \mu \mathrm{g} / \mathrm{L})$ at near the point source of UFFL $\left(\mathrm{F}_{\mathrm{SW} 2}\right)$ and the second highest concentration was recorded $(40.26 \mu \mathrm{g} / \mathrm{L})$ at near the PUFFL point source $\left(\mathrm{F}_{\mathrm{SW} 4}\right)$. In pre-monsoon the highest concentration of $\mathrm{Pb}(23.02 \mu \mathrm{g} / \mathrm{L})$ was recorded at the point source of paper mill $\left(\mathrm{P}_{\mathrm{sw} 2}\right)$. The level $(41.24$ to $63.15 \mu \mathrm{g} / \mathrm{L})$ of $\mathrm{Pb}$ found in water in the present study was close to the findings of Ahmed et al. (2009).

Table 2 revealed that the average results of $\mathrm{Pb}$ concentration in present study in sediments $(20.01 \mathrm{mg} / \mathrm{kg}$ ) of Shitalakhya River were lower than Buriganga River but higher than Padma (17.00 mg/kg) and Jamuna River (19.00 mg/kg). The average concentrations of $\mathrm{Pb}$ in sediment $(20.01 \mathrm{mg} / \mathrm{kg})$ and soil $(28.21 \mathrm{mg} / \mathrm{kg})$ of the present study was lower than Ahmad et al. (2010), Mohiuddin et al. (2011), Saha and Hossain 
(2011) and found the average $\mathrm{Pb}$ concentration in sediments of Buriganga River to be $69.75,478.00$ and $79.40(\mathrm{mg} / \mathrm{kg})$, respectively.

Table 2. Comparison of $\mathrm{Pb}$ in sediments and soils of Shitalakhya River with previous study of different rivers and reference value in the Bangladesh $(\mathrm{mg} / \mathrm{kg})$.

\begin{tabular}{|c|c|c|c|c|}
\hline & Study area & $\begin{array}{l}\text { Conc. } \\
\text { mean }\end{array}$ & Range & Reference/ source \\
\hline \multirow{5}{*}{$\begin{array}{l}\text { Reference } \\
\text { value }\end{array}$} & & 20 & & $\begin{array}{l}\text { a(ASV) (Turekian and } \\
\text { Wedepohl 1961) }\end{array}$ \\
\hline & & 17 & & $\begin{array}{l}{ }^{b} \mathrm{CRC} \text { (Rudnick and Gao } \\
\text { 2003) }\end{array}$ \\
\hline & & 31 & & ${ }^{\mathrm{c}}$ TRV (US EPA 1999) \\
\hline & & 31 & & ${ }^{\mathrm{d}}$ LEL (Persuad 1993) \\
\hline & & 250 & & SEL \\
\hline \multirow{6}{*}{$\begin{array}{l}\text { Bangladeshi } \\
\text { river } \\
\text { Previous } \\
\text { study }\end{array}$} & Shitalakhya River & 60.21 & $54.52-65.90$ & Ahmed et al. (2009) \\
\hline & ${ }^{\mathrm{e}}$ Padma & 17.00 & & \multirow{2}{*}{$\begin{array}{l}\text { eDatta and Subramanian } \\
\text { (1998) }\end{array}$} \\
\hline & ' Jamuna & 19.00 & & \\
\hline & Buriganga River & 69.75 & $65.18-77.13$ & Ahmad et al. (2010) \\
\hline & Buriganga River & 478.00 & $79.0-1552.0$ & Mohiuddin et al. (2011) \\
\hline & Buriganga River & 79.40 & $\begin{array}{l}60.30- \\
105.60\end{array}$ & Saha and Hossain (2011) \\
\hline \multirow[t]{2}{*}{$\begin{array}{l}\text { Bangladeshi } \\
\text { river }\end{array}$} & $\begin{array}{l}\text { Sediments, Shitalakhya } \\
\text { River, } \mathrm{n}=27\end{array}$ & 20.01 & $8.49-75.81$ & Present study \\
\hline & $\begin{array}{l}\text { Soil, Shitalakhya River, } \mathrm{n} \\
=11\end{array}$ & 28.21 & $19.68-85.13$ & Present study \\
\hline
\end{tabular}

${ }^{\mathrm{a} A S V}$ - Average shale value proposed by Turekian and Wedepohl $1961,{ }^{\mathrm{b}} \mathrm{CRC}$ - Continental upper crust values proposed by Rudnick and Gao (2003), ${ }^{\mathrm{c}} \mathrm{TRV}$ - Toxicity reference value proposed by US EPA (1999), ${ }^{\mathrm{d}}$ LEL - Lowest effect level, SEL - Severe effect level, Ontario Ministry of Environment and Energy through aquatic sediment quality guidelines (Persuad et al. 1993) and ${ }^{\mathrm{e}}$ Datta and Subramanian (1998).

Fig. 3 represents the concentration of $\mathrm{Pb}$ in sediments of Shitalakhya River in three seasons. Four samples such as $\mathrm{F}_{\mathrm{sd} 2}, \mathrm{~F}_{\mathrm{sd} 4}, \mathrm{C}_{\mathrm{sd} 1}$ and $\mathrm{P}_{\mathrm{sd} 2}$ were collected from near the point source of urea fertilizer factory (UFF), polash urea fertilizer factory (PUFF), Cement and paper mill, respectively. The highest concentration of $\mathrm{Pb}$ in sediment was recorded (75.81 $\mathrm{mg} / \mathrm{kg}$ ) at near to the point source of urea fertilizer factory in pre-monsoon but in monsoon it was found $29.47 \mathrm{mg} / \mathrm{kg}$. This might have happened due to industrial pollutants were overlapped by natural sediments. The lowest concentration was recorded $(8.49 \mathrm{mg} / \mathrm{kg})$ at near the point source of Seven Ring cement industry in monsoon. Ahmad et al. (2010) previously studied the sediments of Buriganga River and found the highest concentration of $\mathrm{Pb}(77.13 \mathrm{mg} / \mathrm{kg})$ in Balughat during pre-monsoon and the lowest in Shawaryghat in monsoon. The concentration of $\mathrm{Pb}$ at present study point did not exceed the sever effect level (SEL) values, proposed by Ontario Ministry of Environment and 
Energy through aquatic sediment quality guidelines but sampling point $\mathrm{F}_{\mathrm{sd} 2}$ exceeded the lowest effect level (LEL) (Persuad et al. 1993).

On the other hand sampling point $\mathrm{P}_{\mathrm{sd} 3}$ also exceeded the lowest effect level (LEL) but that is not the industrial effect, it may be from natural phenomena such as weathering, seasonal and geological effect.

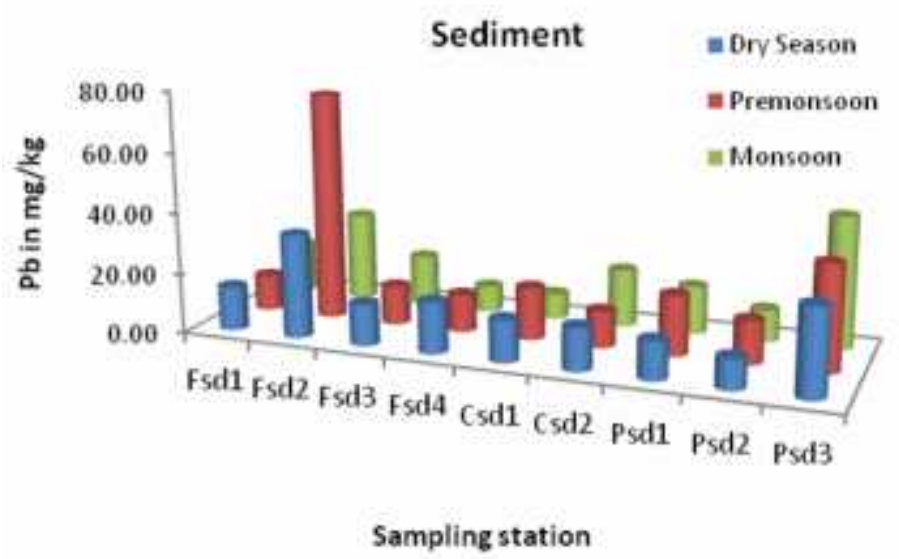

Fig. 3. Seasonal variation of $\mathrm{Pb}$ in sediments at different locations of river (dry wt. $\mathrm{mg} / \mathrm{kg}$ ).

Fig. 4 presents the concentration of $\mathrm{Pb}$ in soils on the bank of Shitalakhya River at pre-monsoon. The highest concentration of $\mathrm{Pb}$ in soil was recorded $(85.13 \mathrm{mg} / \mathrm{kg})$ at near the point source of urea fertilizer factory. The fertilizer industry uses babbitt metal, white metal, and chemicals which were major sources of $\mathrm{Pb}$. The white metal that contain $70-80 \% \mathrm{~Pb}, 15 \% \mathrm{Sb}, 12 \% \mathrm{Sn}, 1.0-1.5 \% \mathrm{Cu}$ is used in plain bearing. The concentrations of $\mathrm{Pb}$ in soils were found within the permissible level of different international standards. Maximum permissible concentration of $\mathrm{Pb}$ in soil in India is $250-500 \mathrm{mg} / \mathrm{kg}$ (Awashthi 2000). 


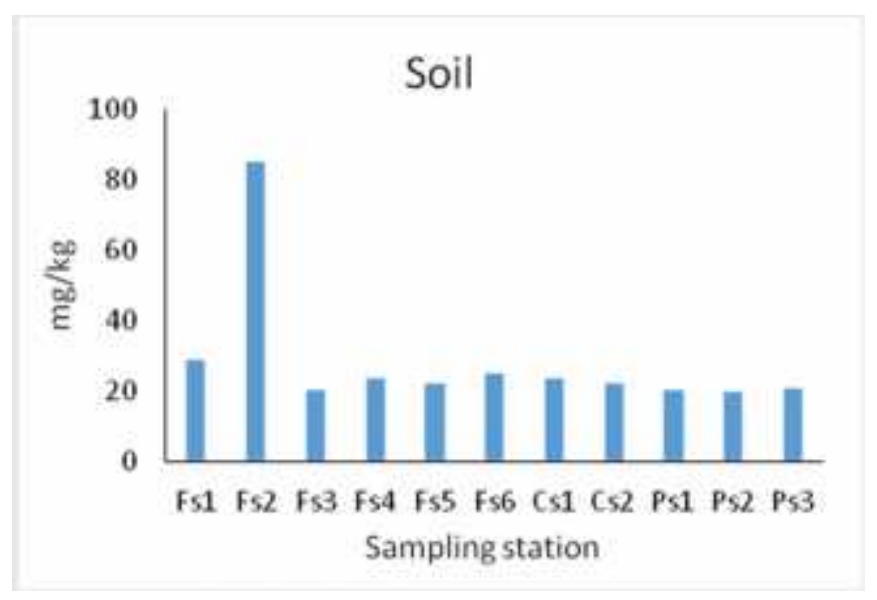

Fig. 4. $\mathrm{Pb}$ in soils $(\mathrm{mg} / \mathrm{kg})$ on the bank of the river at different locations in Pre-monsoon.

Fig. 5 represents the concentrations of $\mathrm{Pb}$ that were found in pumpkin vegetable leaves. These ranged from $1.08-3.92 \mathrm{mg} / \mathrm{kg}$ and alligator weeds from $4.22-1.08 \mathrm{mg} / \mathrm{kg}$. The highest concentration of $\mathrm{Pb}$ in pumpkin vegetable leaves and alligator weeds were recorded 3.92 and $4.22 \mathrm{mg} / \mathrm{kg}$, respectively, at near the point source of urea fertilizer factory which were also within the safe limit of FAO/WHO $(5.0 \mathrm{mg} / \mathrm{kg})$ and SEPA (2005) $(9.0 \mathrm{mg} / \mathrm{kg}$ ) but exceeded the Indian standard $2.5 \mathrm{mg} / \mathrm{kg}$ (Awashthi 2000). Sources of heavy metals for plants include rainfall in atmospheric polluted areas, high discharge of exhaust effluents, indiscriminate disposal of different types of $\mathrm{Pb}$ based white metal, solid wastages of bearing, babbitt metal and chemicals which could be absorbed by different plant through leaf blades and uptake by plant roots. Babbitt metal is most commonly used as a thin surface layer in a complex, multi-metal structure. Moreover, the concentrations of essential elements in plants is affected by the characteristics of the soil and the ability of plants to select and accumulate some metals.

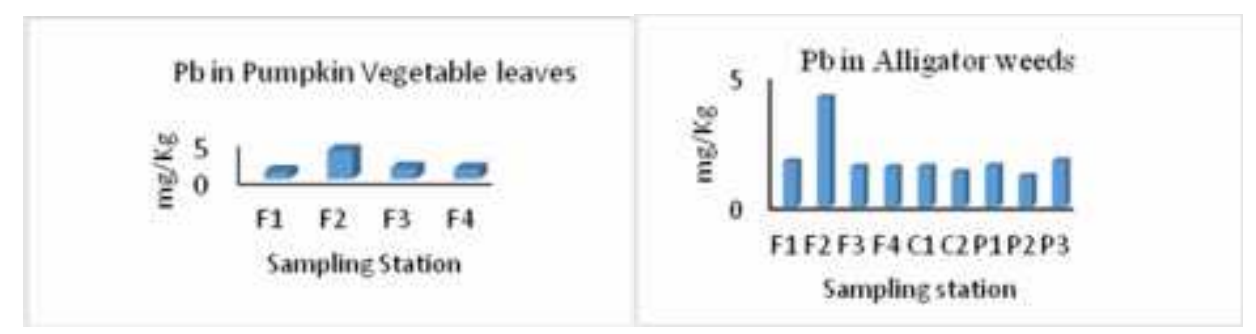

Fig. 5. $\mathrm{Pb}$ in pumpkin vegetable leaves and alligator weeds in pre-monsoon (dry basis) on the bank of Shitalakhya river.

\section{CONCLUSION}

The highest concentration of $\mathrm{Pb}$ in water, sediment and soil was recorded at the point 
source adjacent to the urea fertilizer factory (UFF) in every season. Different types of alloy of white metal is used in heavy duty pumps and high pressure compressors of ammonia, urea and power plant of UFF. Tin-lead alloys such as babbitt metal have a low melting point that is ideal for using as solder, but these alloys also have ideal characteristics for plain bearings. Lead foil is used as gland packing and lead ware is used in bearing clearance of heavy duty pump and compressors. The industrial spare parts undergoing various types of repairs, mechanic workshops, heavy exhaust emissions and heavy duty vehicles, lorries may be the primary source of pollution to the point source of urea fertilizer factory. $\mathrm{Pb}$ concentration in sediment was found to decrease in order of Pre-monsoon < dry- season < monsoon. Although the concentrations of $\mathrm{Pb}$ in soils and sediments are lower than the safe recommended value but alligator weed and pumpkin vegetable leaves inside the UFF and its point source area exceeded the safe limit of Indian standard. The observed alligator weed and pumpkin vegetables leaves in the soil near point source will, in the long run, endanger consumer's health since the ingested heavy metals bioaccumulates in the human body. Moreover, with the gradual development of industries, intensive use of pesticides and discharge of untreated industrial effluent may further exacerbate the situation in coming years.

\section{ACKNOWLEDGEMENTS}

The authors like to thank Md. Hamidul Hoque, Additional Chief Chemist, Analytical Chemistry and Environmental Science Department, Training Institute for Chemical Industries (TICI), Polash, Narsingdi for the instrumental support.

\section{REFERENCES}

Adriano, D. C. 2001. Trace Elements in Terrestrial Environments. $2^{\text {nd }}$ edition. Springer-Verlag, New York, USA. pp. 866.

Ahmad, M. K., S. Islam, S. Rahman, M. R. Haque and M. M. Islam. 2010. Heavy metals in water, sediment and some fishes of Buriganga river, Bangladesh. Int. J. Environ. Res. 4(2): 321-332.

Ahmed, M. K., A. C. Bhowmik, S. Rahman, M. R. Haque, M. M. Hasan and A. A. Hasan. 2009. Heavy metal concentrations in water, sediments and their bioaccumulations in fishes and oyster in Shitalakhya River. Terres. Aquatic Environmental Toxicology, 3(1): 28-32.

APHA, 1989. Standard methods for the examination of water and waste water, $17^{\text {th }}$ edition, American Public Health Association. Washington DC. 3030E. pp. 3-8.

ASTM Standards. 2003. Standard practice for total digestion of sediment samples for chemical analysis of various metals. Water and Environmental Technology. Section 11, 11(02): 616618.

Awashthi, S. K. 2000. Prevention of Food Adulteration Act No. 37 of 1954, Central and State rules as amended for 1999 ( $3^{\text {rd }}$ ed.), Ashoka Law House, New Delhi.

Codex Alimentarious Commission. 1984. Contaminants, Joint FAO/WHO Food Standards Program (Vol. XVII, $1^{\text {st }}$ ed.). 
Datta, D. K. and V. Subramanian. 1998. Distribution and fractionation of heavy metals in the surface sediments of the Ganges-Brahmaputra-Meghna river system in the Bengal basin. Environ. Geol. 36(1-2): 93-101.

Dahiya, S., R. Karpe, AG Hegde and RM Sharma. 2005. Lead, cadmium and nickel in chocolate and candies from suburban areas of Mumbai, India. J. Food Comp. Anal. 18: 517-22

Mohiuddin, K. M., Y. Ogawa, H. M. Zakir, K. Otomo and N. Shikazono. 2011. Heavy metals contamination in water and sediments of an urban river in a developing country. Int. $J$. Environ. Sci. Tech. 8 (4): 723-736.

Persuad, D., R. Jaagumagi and A. Hayton. 1993. Guidelines for the protection and management of aquatic sediment quality in Ontario. Ontario Ministry of the Environment, Canada.

Rudnick, R. L. and S. Gao. 2003. Treatise on Geochemistry. Editor: Roberta L. Rudnick. Executive Editors: Heinrich D. Holland and Karl K. Turekian, 3: 659.

Saha, P. K. and M. D. Hossain. 2011. Assessment of heavy metal contamination and sediment quality in the Buriganga river, Bangladesh. $2^{\text {nd }}$ International Conference on Environmental Science and Technology IPCBEE 2011, vol. 6, IACSIT Press, Singapore.

SEPA. 2005. The Limits of Pollutants in Food. China: State Environmental Protection Administration, GB2762-2005.

Sittig, M. 1991. Handbook of Toxic and Hazardous Chemicals and Carcinogens, ( ${ }^{\text {rd }}$ edition), Noyes Publication, Park Ridge, New Jersey, USA, 1: 973.

Sullivan, D. M. and D. E. E. Carpenter. 1993. Metals in Plants. Methods of Analysis for Nutritional Labeling, AOAC International, Arlington, VA. pp.152-155.

Turekian, K. K. and K. H. Wedepohl. 1961. Distribution of the elements in some major units of the earth's crust. Geol. Soc. Am. Bull. 72 (2): 175-192.

US EPA. 1999. Screening level ecological risk assessment protocol for hazardous waste combustion facilities, Vol. 3, Appendix E: Toxicity reference values. EPA 530-D99-001C. 